Article

\title{
Foreign Shareholders' Social Responsibility, R\&D Innovation, and International Competitiveness of Chinese SOEs
}

\author{
Yuying Zhou ${ }^{1, *(\mathbb{D})}$, Chu Lei ${ }^{1}$ and Alfredo Jiménez ${ }^{2} \mathbb{D}$ \\ 1 School of Business English, Sichuan International Studies University, Chongqing 400013, China; \\ leichu@stu.sisu.edu.cn \\ 2 Department of Management, KEDGE Business School, 31405 Talence, France; alfredo.jimenez@kedgebs.com \\ * Correspondence: zhouyuying@sisu.edu.cn
}

check for

updates

Citation: Zhou, Y.; Lei, C.; Jiménez, A. Foreign Shareholders' Social Responsibility, R\&D Innovation, and International Competitiveness of

Chinese SOEs. Sustainability 2022, 14, 1746. https://doi.org/10.3390/ su14031746

Academic Editor: Carlos

Rodríguez Monroy

Received: 28 December 2021

Accepted: 19 January 2022

Published: 2 February 2022

Publisher's Note: MDPI stays neutral with regard to jurisdictional claims in published maps and institutional affiliations.

Copyright: (C) 2022 by the authors. Licensee MDPI, Basel, Switzerland. This article is an open access article distributed under the terms and conditions of the Creative Commons Attribution (CC BY) license (https:// creativecommons.org/licenses/by/ $4.0 /)$.

\begin{abstract}
Despite the increasing use of mixed ownership (domestic and foreign shareholders) in Chinese state-owned enterprises (SOEs), the role and performance of foreign ownership is still a controversial topic. In this paper we empirically examine the effects of foreign shareholders' social responsibility on the international competitiveness of SOEs and the moderating effect of R\&D innovation. Drawing on a sample of Chinese listed SOEs with international market operations over the period 2011-2019, we find empirical evidence supporting that foreign shareholders' social responsibility is effective in enhancing the international competitiveness of Chinese SOEs. We also find that R\&D innovation strengthens the effect between foreign shareholders' social responsibility and enterprises' international competitiveness. These findings are valid after controlling for robustness and endogeneity factors. Furthermore, we find that the promoting effect of foreign shareholders' social responsibility on Chinese SOEs' international competitiveness, as well as the moderating effect of R\&D innovation, is more pronounced among Chinese local SOEs, business SOEs, and manufacturing SOEs. The research in this paper contributes to the current debate and deepens our understanding regarding the role and performance of foreign shareholders in the process of mixed-ownership reform.
\end{abstract}

Keywords: international competitiveness; foreign shareholders' social responsibility; R\&D innovation; Chinese SOEs

\section{Introduction}

As an essential part of China's economic development after its reform and opening up, foreign investment in China has undergone a gradual evolution from quantity to quality in both development scale and quality after the pilot start-up stage, rapid development stage, high-level development stage, and new stage of all-round opening up. Quantitatively, the total actual utilization of foreign capital in China has increased more than 60 times from USD 2.260 billion in 1983 to USD 138.135 billion in 2019 (see Figure 1). Foreign capital has helped China move into a new stage of high-quality economic development through the economic growth effect, industrial structure upgrading effect, income effect, etc. [1,2]. In recent years, along with the advance of a mixed-ownership reform of Chinese SOEs, foreign shareholders have not only brought more capital, resources, and experience in the process of entering Chinese SOEs, but also upgraded enterprises' governance mechanisms by reducing the cost of Chinese state-owned agents. Finally, the business performance of Chinese SOEs has been well improved $[3,4]$.

However, in the process of Chinese SOEs utilizing foreign capital, problems such as misconceptions about foreign shareholders, poor utilization of foreign capital, and the late priority of foreign shareholders during mixed-ownership reform have partly curbed the performance of foreign shareholders. In this regard, the report of the 19th National Congress of the Communist Party of China clearly states that it is necessary to "deepen the reform of 
state-owned enterprises, develop a mixed-ownership economy, and cultivate world-class enterprises with global competitiveness". The introduction of foreign shareholders would help Chinese SOEs solve the problem of combining Chinese state-owned capital with a market economy, boost the marketization of Chinese SOEs, and especially provide Chinese SOEs with better access to international markets. Besides, the organic integration between Chinese state-owned capital and foreign capital is expected to improve the liquidity of Chinese state-owned capital, build up complementary strengths of different kinds of capital, and make Chinese SOEs more internationally competitive [5]. However, these expectations have not been adequately analyzed empirically in the literature. To address this gap in the literature, in this paper we study the international competitiveness of Chinese SOEs from the perspective of foreign shareholders' social responsibility not only to provide a new perspective on the study of the mixed-ownership reform of Chinese SOEs at the theoretical level, but also to empirically analyze Chinese SOEs' sustainable development in the context of global economic integration at the practical level.

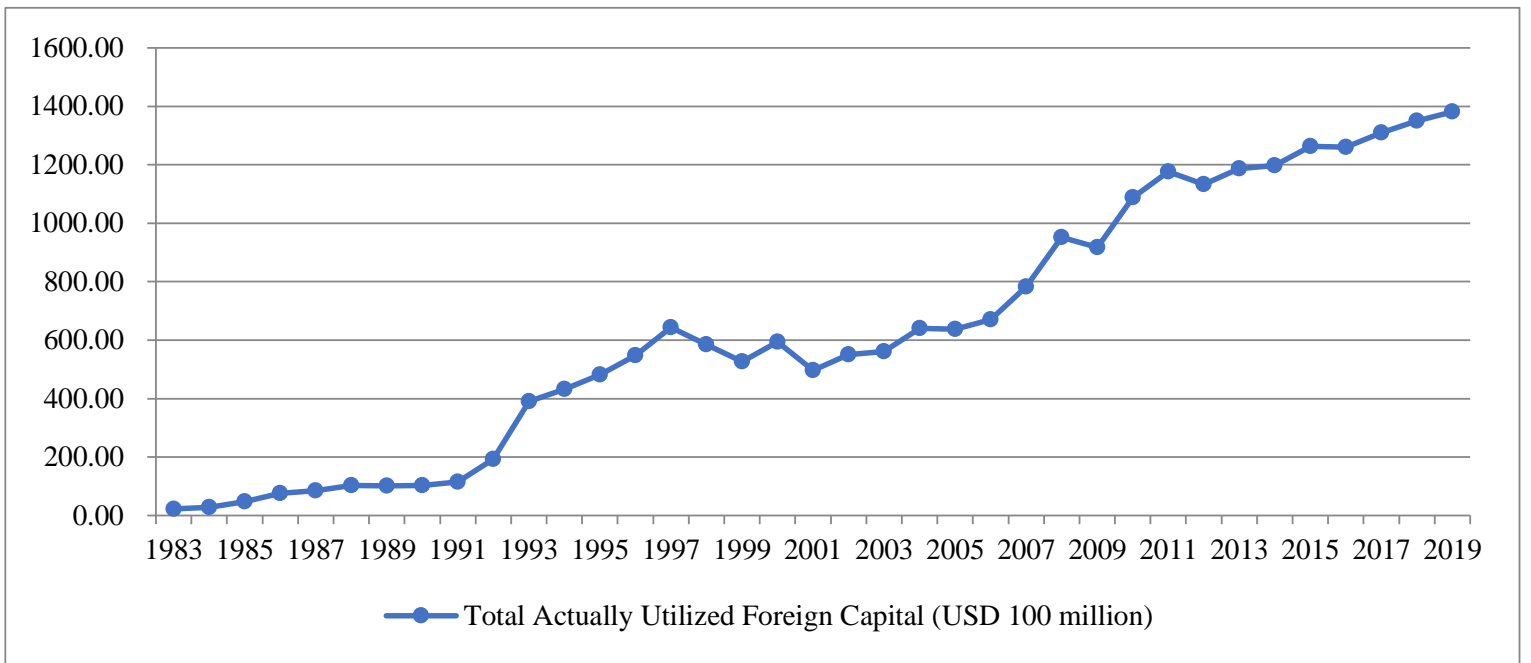

Figure 1. Total actual utilization of foreign investment in China from 1983 to 2019.

The arrival of foreign shareholders in Chinese SOEs offers sufficient capital elements, advanced technology, as well as desirable social responsibility concepts and practices. Since foreign shareholders tend to introduce their own advanced and mature social responsibility concepts to enterprises, they would serve as a demonstration to motivate enterprises to better fulfill their social responsibility through learning and imitation [6]. The existing literature also indicates that the inclusion of foreign shareholders has played a constructive role in elevating the social responsibility commitment of Chinese enterprises. Thus, previous studies underline that the inclusion of foreign shareholders efficiently reduces the incidence of labor workers' rights being violated in domestic enterprises [7], witnessing an improvement in employees' rights and interests in corporate social responsibility (CSR). It has been pointed out that Chinese enterprises tend to bring in foreign shareholders from developed regions such as Europe and the United States who generally place more emphasis on social responsibility, leading Chinese enterprises to better perform CSR correspondingly [8]. Also, it has been suggested that the presence of foreign shareholders actively affected Chinese enterprises' CSR performance through the channel of supply chain pressure [9], and that the entry of foreign shareholders is an incentive to foster social responsibility in host enterprises since a higher shareholding ratio is a prerequisite for making foreign shareholders work [10].

However, the existing literature only presents empirical evidence that the introduction of foreign shareholders enables host enterprises to deliver better CSR performance without considering the economic consequences brought along with it. For instance, China's exportoriented economy has made it possible for Chinese SOEs to introduce foreign shareholders. 
The empirical evidence that the existing literature fails to deliver regards whether the introduction of foreign shareholders into Chinese SOEs is able to help Chinese SOEs better adapt to the international market and sharpen their international competitiveness, supposing that foreign shareholders will perform their social responsibilities well. We precisely aim to fill this gap in the literature and thus advance collective wisdom on the international competitiveness of Chinese SOEs. From a theoretical point of view, foreign shareholders can effectively attract more overseas investors for Chinese SOEs by fulfilling their social responsibility and satisfying the interests of different stakeholders, thereby making Chinese SOEs with better CSR engagement dominate and stand out in the international market. Furthermore, foreign shareholders' actions on social responsibility will upgrade Chinese SOEs' CSR performance and help create a sound image in overseas markets, making it easier for Chinese SOEs to explore international markets, build brands, and improve their international competitiveness.

Foreign shareholders value social responsibility fulfillment as well as R\&D innovation. Foreign shareholders aim for better R\&D innovation, technology spillovers, and improved productivity when supervising the management of Chinese SOEs [11]. The presence of foreign shareholders can effectively help Chinese SOEs develop technology while exploring capital and markets, sharpen R\&D edges, reduce related costs, and gain a competitive advantage in the international market. At the same time, $R \& D$ innovation constitutes an important part of foreign shareholders' social responsibility. Foreign shareholders require enterprises to place great emphasis on CSR performance while developing new products, technologies, and business models, contributing to a virtuous cycle in social responsibility fulfillment, R\&D investment, and market competition [12].

We empirically examine the impact of foreign shareholders' social responsibility on the competitiveness of Chinese SOEs, and the moderating effect of R\&D innovation, based on the sample of Chinese SOEs with international market operations during 2011-2019. Our study makes several contributions: first, by focusing on foreign shareholders we contribute to extending the relatively scarce literature on the mixed-ownership reform of Chinese SOEs, and we do so by analyzing the benefits that foreign shareholders can bring to Chinese SOEs. Second, we delineate the social-responsibility-related mechanism through which foreign shareholders play an important role in and affect the international competitiveness of Chinese SOEs. Third, we provide empirical evidence on the improvement of international competitiveness in Chinese SOEs when foreign shareholders are included, which can be of great reference value to Chinese SOEs implementing mixed-ownership reforms and policy-makers of related policies.

\section{Theoretical Analysis and Research Hypotheses}

\subsection{Foreign Shareholders' Social Responsibility and Enterprises' International Competitiveness}

A number of enterprises in Asian emerging-capital-market countries, especially Chinese ones, tend to bring in foreign shareholders from developed European and American countries with Western management practices. These foreign shareholders normally not only require themselves to fulfill their own social responsibility, but also infuse this selfbehavior into the enterprise as a way of improving overall social responsibility concepts and standards $[13,14]$. Foreign shareholders face the disadvantage of being outsiders in the process of entering the host-country enterprises. Therefore, social responsibility represents a good tool for foreign shareholders to protect their own interests, which includes, first, the protection of foreign shareholders' interests, and second, the need for foreign shareholders to reduce information asymmetry between themselves and management through disclosure of social responsibility information, so as to mitigate the loss of interests caused by information discrepancies [15]. Given this, in the process of fulfilling social responsibility, foreign shareholders typically try to strengthen the firm's international competitiveness by emphasizing CSR performance as well as business performance, etc.

The fulfillment of social responsibility by foreign shareholders produces a competitive effect, prompting enterprises to explore special resources suitable for their own develop- 
ment, thus sharpening their competitive edge. Foreign shareholders come with more capital in the process of entering Chinese enterprises, and this capital exists both within the enterprise and within the industry, pushing both competitions forward. Foreign shareholders' acting on social responsibility reallocates corporate resources since enterprises' own operating costs and relationships with others in the industry are affected, which in turns shapes enterprises' competitive advantage [16]. In particular, as market consumers are sensible to CSR, they are more likely to purchase products from socially responsible companies, and the phenomenon exists in both domestic and international markets [17]. This allows shareholders to put more emphasis on social responsibility as well as its performance, and makes enterprises willing to obtain the economic foundation to be internationally competitive by fulfilling social responsibility. Besides, foreign shareholders' performing social responsibility will bring enterprises more special resources, particularly resources in overseas markets such as goodwill in international markets to create a favorable external environment and shape unique internal competitiveness in international market competition.

Moreover, foreign shareholders' social responsibility performance has a demonstration effect, motivating other shareholders to do the same and thus shaping competitiveness of enterprises commonly. Foreign shareholders bring advanced and mature social responsibility concepts of their home countries to the investee companies and integrate their own social responsibility preferences in the process of corporate governance, providing access to other shareholders to improve their own social responsibility performance through learning and imitation, guiding the investee companies to make more decisions favoring social responsibility undertakings [13]. The demonstration role enables enterprises faced with international market competition to provide upstream enterprises with higherquality intermediate products and more comprehensive after-sales services, etc., so as to improve product and service quality. Advanced technology, information, organizational management mechanisms, etc., are expected to support downstream enterprises to assist the supplier in providing qualified raw materials $[18,19]$. As a result, foreign shareholders, by fulfilling their social responsibility, inject sustainability and long-term development prospects into the international market competition in shaping better international community relations and generating desirable long-term financial performance [20]. In this way, both the economic value and the international competitiveness of enterprises are raised [21].

Finally, the social responsibility behavior of foreign shareholders creates a signaling effect and delivers more information related to enterprises to the international market, contributing to a favorable atmosphere for enhancing its international competitiveness. Foreign shareholders aim to build their strengths in the international market by fulfilling their social responsibility, proactively sending positive signals to their stakeholders, spreading internal management results to international markets in different dimensions, generating positive feedback benefits, and further directing the inflow of international resources [22]. Besides, as one of the stakeholders, foreign shareholders' positive social responsibility signals can reduce the agency costs between them and the management as well as minimize moral hazard and adverse selection caused by information asymmetry. In this connection, the uncertainty of engaging in international markets is lowered, and enterprises are led toward better access to international market resources while maintaining and consolidating relationships with global customers and suppliers, thus laying a solid foundation to be internationally competitive [23].

We therefore propose the following research hypothesis:

Hypothesis 1 (H1). There is a positive relationship between the social responsibility of foreign shareholders and the international competitiveness of enterprises. 


\subsection{Foreign Shareholders' Social Responsibility, RED Innovation, and Enterprises' International Competitiveness}

As global science and technology advance, the innovation-driven model has emerged as a new model for sustainable economic growth across the world. Enterprises in various countries have been engaged in enhancing efficiency and deepening the effect of R\&D innovation by pouring upfront investment into it in the hope of delivering better performance in international competition [24]. The inclusion of R\&D innovation while formulating development strategy motivates enterprises to secure sustainable development and consolidate their existing competitive advantage in order to put themselves in a more favorable position in market competition [25]. Chinese listed SOEs involved in international competition mainly resorted to low-priced labor for gaining advantages in labor-intensive industries in the early years, but currently they stand out in technology-intensive industries with top-notch technological advances as well. In fact, the contribution of R\&D innovation to China's economic growth has increased from $31.46 \%$ in 1991 to $58.36 \%$ in 2017 [26]. Given the current global digital economy, the continuous flow of data from R\&D to production and from sales to service during use is what it takes to make enterprises continuously create economic value and elevate competitiveness [27]. It is noticeable that R\&D innovation, which has received a lot of attention from an increasing number of Chinese companies, can also function as a new driving force to lead Chinese enterprises to compete in the international market.

Foreign shareholders have also realized the importance of R\&D innovation. For enterprises in emerging markets, a motive for introducing foreign shareholders is to create technology spillover and technology transfer effects with technological advantages brought by foreign shareholders, thereby driving their own technological progress [28]. Similarly, in the process of fulfilling social responsibility, foreign shareholders also stress the need to enhance social responsibility performance by practical effects of promoting R\&D innovation. Foreign shareholders, by fulfilling their social responsibility, can reduce various risk constraints that may exist in $R \& D$ innovation activities, thus increasing related future benefits. Although R\&D innovation activities may restrict resources and capital due to their higher cost, social responsibility, as an intangible resource, works to help enterprises capture consumer brand loyalty as well as a good reputation and to foster investors' confidence. What is more, foreign shareholders own the foundation for implementing $R \& D$ innovation, thus ensuring that they can achieve the goal of fulfilling social responsibility through feasible R\&D innovation activities [29]. Furthermore, R\&D innovation and social responsibility are mutually promoted, allowing foreign shareholders to leverage the effect of R\&D innovation activities to enhance social responsibility performance. CSR and R\&D innovation are capital investment activities with similarities, bringing enterprises favorable social and moral capital as well as positive feedback from capital markets [30]. It is noteworthy that R\&D innovation activities will be gradually optimized during CSR performance, and more R\&D investment along with it will promote CSR performance and improve innovation capacity, contributing to a "win-win" solution [31].

We contend that R\&D innovation might affect the relationship between the social responsibility of foreign shareholders and the international competitiveness of enterprises. Firstly, the complementarity between R\&D innovation and social responsibility enables $R \& D$ innovation to mitigate the increased costs of social responsibility to a certain extent and better facilitate foreign shareholders to enhance their international competitiveness by social responsibility engagement. Since foreign shareholders with a better performance of social responsibility tend to think highly of R\&D innovation activities, they are more courageous in bearing the risks of R\&D innovation and work hard to make it targeted and feasible [32]. Foreign shareholders may use possible future benefits of R\&D innovation to compensate for current costs of fulfilling social responsibility and minimize the uncertainty of future benefits for different stakeholders. Therefore, foreign shareholders will actively promote R\&D the innovation behaviors of enterprises, especially internationally, during social responsibility performance as a way of establishing R\&D innovation in interna- 
tional markets and enhancing the international competitiveness of enterprises. Secondly, $R \& D$ innovation is expected to be an effective channel for foreign shareholders' social responsibility to promote the international competitiveness of enterprises, encouraging foreign shareholders to complete social responsibility performance with $R \& D$ innovation. Accordingly, both performance effects and international competitiveness are improved. During this process, foreign shareholders can reduce heterogeneous resources required for their R\&D innovation. For instance, capital and technology advantages of foreign shareholders, competitive advantage, demonstration advantage, and signal advantage generated by social responsibility of foreign shareholders achieve full utilization. Sound $R \& D$ innovation and social responsibility of foreign shareholders are better signaled to the capital and business markets [33].

We therefore propose the following research hypothesis:

Hypothesis 2 (H2). RED innovation strengthens the positive relationship between foreign shareholders' social responsibility and enterprises' international competitiveness.

\section{Study Design}

\subsection{Variable Design}

\subsubsection{Dependent Variable: International competitiveness}

International competitiveness (IC): Building on [34], this paper constructs an international competitiveness indicator system based on four dimensions: management ability, financial status, investment performance, and development potential, as shown in Table 1. The indicators selected in Table 1 are homogenized and then standardized in accordance with the Z-value method, after which the international competitiveness index of Chinese SOEs is constructed in factor analysis.

Table 1. The international competitiveness evaluation system of Chinese listed SOEs.

\begin{tabular}{|c|c|c|c|}
\hline First Level Indicators & Second Level Indicators & Third Level Indicators & Attribute \\
\hline \multirow{3}{*}{ Management ability } & Market scale & $\begin{array}{c}\text { Market value per share, net profit per share, } \\
\text { net assets per share }\end{array}$ & Positive indicators \\
\hline & Ownership concentration & $\begin{array}{l}\text { Shareholding ratio of the first largest } \\
\text { shareholder, concentration of shares held by } \\
\text { top ten shareholders }\end{array}$ & Positive indicators \\
\hline & Insider incentive & $\begin{array}{c}\text { Executive compensation level, executive } \\
\text { shareholding ratio }\end{array}$ & Positive indicators \\
\hline \multirow{5}{*}{ Financial Status } & \multirow[t]{2}{*}{ Viability } & \multirow{5}{*}{$\begin{array}{c}\text { Liquidity ratio, quick ratio, total } \\
\text { asset turnover } \\
\text { Asset-liability ratio } \\
\text { Net profit margin, return on total assets, } \\
\text { return on equity, return on invested capital } \\
\text { Ratio of sales to cost } \\
\text { Total assets growth rate, increase rate of main } \\
\text { business revenue, net profit growth rate, } \\
\text { equity multiplier }\end{array}$} & Positive indicators \\
\hline & & & Negative indicators \\
\hline & Profitability & & Positive indicators \\
\hline & & & Negative indicators \\
\hline & Developing ability & & Positive indicators \\
\hline \multirow{3}{*}{ Investment performance } & Market performance & Alpha, Beta, Sharpe & Positive indicators \\
\hline & \multirow{2}{*}{ Valuation ability } & Price earnings ratio, price-to-book ratio & $\begin{array}{l}\text { Moderation } \\
\text { indicators }\end{array}$ \\
\hline & & $\begin{array}{l}\text { Dividend yield ratio, earnings per share, free } \\
\text { cash flow per share }\end{array}$ & Positive indicators \\
\hline \multirow{3}{*}{ Development potential } & Growth potential & \multirow{3}{*}{$\begin{array}{l}\text { Proportion of intangible assets to total assets, } \\
\text { proportion of fixed assets to total assets } \\
\text { proportion of R\&D expenses to total assets } \\
\text { Proportion of overseas revenue to } \\
\text { operating revenue }\end{array}$} & Positive indicators \\
\hline & R\&D ability & & Positive indicators \\
\hline & Degree of internationalization & & Positive indicators \\
\hline
\end{tabular}


3.1.2. Independent Variable: Social Responsibility of Foreign Shareholders

Social Responsibility of Foreign Shareholders (SRFS): Hexun.com (www.hexun.com, accessed on 15 February 2021) provides the total social responsibility score of Chinese listed companies based on a comprehensive consideration of corporate responsibility to shareholders, employees, suppliers, customers and consumers, the environment, and society. Higher scores imply better CSR performance. Since the score includes shareholder responsibility efforts and the study mainly focuses on the score for the social responsibility of foreign shareholders, the score is multiplied by the shareholding ratio of foreign shareholders to obtain the social responsibility performance that foreign shareholders achieved. Likewise, a higher calculated score means better social responsibility fulfillment of foreign shareholders.

\subsubsection{Moderating Variable: R\&D innovation}

$R \mathcal{E} D$ Innovation $(R \mathcal{E} D)$ : This variable is based on the natural logarithm of annual $R \& D$ investment of the focal Chinese SOE.

\subsubsection{Controlled Variables}

Building on previous research, the following controlled variables are included in the model.

Enterprise Attribute (EA): measured as the attribute of whether the sample enterprise is a Chinese central SOE or a local SOE; EA $=1$ if the sample enterprise is Chinese central $\mathrm{SOE}$, otherwise $\mathrm{EA}=0$.

Total Assets (TA): measured as the natural logarithm of the total assets of the sample enterprise at the end of the year.

Asset-liability Ratio (ALR): measured as the ratio of total liabilities to total assets of the sample enterprise at the end of the year.

Return on Assets (ROA): measured as the ratio of net income to average total assets of the sample enterprise at the end of the year.

Ownership Concentration (OC): measured by the sum of squared shareholdings of the top 10 shareholders of the sample enterprise at the end of the year.

Proportion of Independent Directors (PID): measured by the proportion of independent directors to the board of directors of the sample enterprise at the end of the year.

\subsection{Empirical Model Design}

\subsubsection{Baseline Regression Test Model Design}

To explore the relationship between the social responsibility of foreign shareholders and the international competitiveness of enterprises, we tested the following empirical regression model:

$$
I C_{\mathrm{i}, \mathrm{t}}=\alpha_{1} S R F S_{\mathrm{i}, \mathrm{t}}+\alpha_{\mathrm{i}} \text { Control_Variable }_{\mathrm{i}, \mathrm{t}}+\text { Year }+ \text { Industry }+C+\varepsilon_{\mathrm{i}, \mathrm{t}}
$$

In addition, in order to examine the moderating effect of R\&D innovation in the relations between foreign shareholders and the international competitiveness of enterprises, we tested the following empirical model:

$$
\begin{gathered}
I C_{\mathrm{i}, \mathrm{t}}=\alpha_{1} S R F S_{\mathrm{i}, \mathrm{t}}+\alpha_{2} S R F S_{\mathrm{i}, \mathrm{t}} \times R \& D_{\mathrm{i}, \mathrm{t}}+\alpha_{3} R \& D_{\mathrm{i}, \mathrm{t}}+\alpha_{\mathrm{i}} \text { Control }_{\text {Variable } \mathrm{i}, \mathrm{t}} \\
+Y e a r+\text { Industry }+C+\varepsilon_{\mathrm{i}, \mathrm{t}}
\end{gathered}
$$

In Equations (1) and (2), Control_Variable is control group and C is the constant term. Both the annual factor (Year) and the industry factor (Industry) of the sample enterprises are controlled.

\subsubsection{Endogeneity Test Model Design}

A possible endogeneity relationship between the social responsibility of foreign shareholders and the international competitiveness of enterprises should be taken into account, 
i.e., foreign shareholders may deliberately fulfill their social responsibility in light of some external factors, resulting in a spurious relationship between the social responsibility of foreign shareholders and international competitiveness. Therefore, we employed the Heckman two-stage regression model for endogeneity testing. In this case, the first stage works to estimate instrumental variables on explanatory variables $S R F S_{i, t}$, namely:

$$
S R F S_{\mathrm{i}, \mathrm{t}}=\alpha_{1} T P A_{\mathrm{i}, \mathrm{t}}+\alpha_{\mathrm{i}} \text { Control_Variable }_{\mathrm{i}, \mathrm{t}}+\text { Year }+ \text { Industry }+C+\varepsilon_{\mathrm{i}, \mathrm{t}}
$$

In Equation (3), the variable $T P A_{i, t}$ is an instrumental variable, measured as a dummy variable of whether the sample enterprise is engaged in targeted poverty alleviation, i.e., if yes, $T P A_{i, t}=1$, otherwise $T P A_{i, t}=0$. The reason for choosing this instrumental variable is that, firstly, targeted poverty alleviation has represented an important solution for fighting poverty in China in recent years. Chinese SOEs, as an essential mainstay of China's economic development, play a major role in this fight. Meanwhile, foreign shareholders rise as new forces, indicating that foreign shareholders who are willing to participate in targeted poverty alleviation will better perform their social responsibility. Therefore, the instrumental variable is proved to be relevant. Secondly, whether enterprises are engaged in targeted poverty alleviation or not makes no difference to their international competitiveness, and the exogeneity condition of instrumental variables is satisfied as well.

\subsection{Data Selection and Description}

Since many Chinese SOEs have undergone mixed-ownership reform by introducing foreign shareholders for the past few years, a rising number of them have opted to enhance their competitiveness through international markets along with the growth of China's export-oriented economy. We selected a sample of Chinese SOEs listed in Shanghai and Shenzhen A-shares with international market operations during 2011-2019 for empirical testing in this paper.

From the initial overall sample, we excluded the following cases: (1) firms in the finance, insurance, and securities industries; (2) firms with special treatment; (3) firms listed for the first time; (4) firms with data missing. Finally, 3030 observations of 641 Chinese listed SOEs during 2011-2019 are included in the final sample.

\section{Results and Analysis of Empirical Tests}

\subsection{Descriptive Statistical Results and Analysis}

Table 2 reports the descriptive statistical results of the full sample. The variable $I C_{i, t}$ has a mean value of 0.190 , which shows that the current international competitiveness of Chinese SOEs is relatively weak, and there exist certain differences in international competitiveness across different Chinese SOEs. The mean value of variable $S R F S_{i, t}$ is 0.367; likewise, Chinese SOEs also differ in their foreign shareholders' social responsibility performance. The mean value of variable $R \& D_{i, t}$ is 15.858 , which is relatively low. The average annual R\&D investment of Chinese SOEs is about 7.71 million RMB; nevertheless, $R \& D$ investment varies greatly among different Chinese SOEs.

Table 3 reports the descriptive statistical results of groups. Regarding the grouping descriptive statistical results with a median value of variable $S R F S_{i, t}$, both mean and median values of variable $I C_{i, t}$ are higher in the high $S R F S_{i, t}$ group, and both met the significance test at the conventional confidence level. Chinese listed SOEs with foreign shareholders better fulfilling social responsibility present higher international competitiveness.

\subsection{Correlation Test Results and Analysis}

Table 4 reports the correlation test results. Firstly, the correlation coefficient values between variable $I C_{i, t}$ and variable $S R F S_{i, t}$ are significantly positive, indicating a positive relationship between foreign shareholders' social responsibility and international competitiveness of Chinese SOEs; the correlation coefficient values between variable $I C_{i, t}$ and variable $R \& D_{\mathrm{i}, \mathrm{t}}$ are also significantly positive, suggesting a positive relationship between $R \& D$ innovation and the international competitiveness of Chinese SOEs. Secondly, the 
correlation coefficient values between the variables are not high, showing that there is no multicollinearity between the variables.

Table 2. Descriptive Statistical Results of Full Sample.

\begin{tabular}{cccccccc}
\hline Variable & Mean & Median & $\begin{array}{c}\text { Standard } \\
\text { Deviation }\end{array}$ & $\mathbf{5 \%}$ & $\mathbf{2 5 \%}$ & $\mathbf{7 5 \%}$ & $\mathbf{9 5 \%}$ \\
\hline$I C_{\mathrm{i}, \mathrm{t}}$ & 0.190 & 0.176 & 0.065 & 0.125 & 0.152 & 0.216 & 0.297 \\
$S R F S_{\mathrm{i}, \mathrm{t}}$ & 0.367 & 0.000 & 1.241 & 0.000 & 0.000 & 0.119 & 2.306 \\
$R \mathcal{E} D_{\mathrm{i}, \mathrm{t}}$ & 15.858 & 17.982 & 6.250 & 0.000 & 16.416 & 19.237 & 20.757 \\
$E A_{\mathrm{i}, \mathrm{t}}$ & 0.286 & 0.000 & 0.452 & 0.000 & 0.000 & 21.000 & 1.000 \\
$T A_{\mathrm{i}, \mathrm{t}}$ & 22.728 & 22.570 & 1.292 & 20.821 & 0.786 & 23.735 & 0.689 \\
$A L R_{\mathrm{i}, \mathrm{t}}$ & 0.522 & 0.532 & 0.198 & 0.184 & 0.023 & 0.070 & 0.128 \\
$R O A_{\mathrm{i}, \mathrm{t}}$ & 0.043 & 0.041 & 0.058 & -0.043 & 0.090 & 0.264 & 0.407 \\
$O C_{\mathrm{i}, \mathrm{t}}$ & 0.180 & 0.155 & 0.123 & 0.034 & 0.333 & 0.429 & 0.500 \\
$P I D_{\mathrm{i}, \mathrm{t}}$ & 0.372 & 0.357 & 0.080 & 0.286 & & &
\end{tabular}

Table 3. Descriptive Statistical Results of Groups.

\begin{tabular}{|c|c|c|c|c|c|c|c|c|}
\hline \multirow{2}{*}{ Variable } & \multicolumn{3}{|c|}{ High $S R F S_{i, t}$} & \multicolumn{3}{|c|}{ Low $S R F S_{\mathbf{i}, \mathbf{t}}$} & \multirow{2}{*}{$T$ Test } & \multirow{2}{*}{ Wilcoxon Z } \\
\hline & $N$ & Mean & Median & $N$ & Mean & Median & & \\
\hline$I C_{\mathrm{i}, \mathrm{t}}$ & 777 & 0.208 & 0.188 & 2253 & 0.183 & 0.172 & $9.358^{* * *}$ & $8.882 * * *$ \\
\hline \multirow{2}{*}{ Variable } & \multicolumn{3}{|c|}{ High $R \mathcal{E} D_{\mathrm{i}, \mathrm{t}}$} & \multicolumn{3}{|c|}{ Low $R \mathcal{E} D_{\mathrm{i}, \mathrm{t}}$} & \multirow{2}{*}{$T$ test } & \multirow{2}{*}{ Wilcoxon Z } \\
\hline & $N$ & Mean & Median & $N$ & Mean & Median & & \\
\hline$I C_{\mathrm{i}, \mathrm{t}}$ & 1515 & 0.198 & 0.181 & 1515 & 0.182 & 0.170 & $6.765^{* * *}$ & $7.262^{* * *}$ \\
\hline
\end{tabular}

Table 4. Correlation Test Results.

\begin{tabular}{|c|c|c|c|c|c|c|c|c|c|}
\hline & $I C_{\mathrm{i}, \mathrm{t}}$ & $S R F S_{\mathrm{i}, \mathrm{t}}$ & $R \mathcal{E} D_{\mathrm{i}, \mathrm{t}}$ & $E A_{\mathrm{i}, \mathrm{t}}$ & $T A_{\mathrm{i}, \mathrm{t}}$ & $A L R_{\mathrm{i}, \mathrm{t}}$ & $R O A_{\mathrm{i}, \mathrm{t}}$ & $O C_{\mathrm{i}, \mathrm{t}}$ & $P I D_{i, \mathrm{t}}$ \\
\hline$I C_{\mathrm{i}, \mathrm{t}}$ & 1 & & & & & & & & \\
\hline$S R F S_{i, t}$ & $0.169^{* * *}$ & 1 & & & & & & & \\
\hline$R \mathcal{E} D_{\mathrm{i}, \mathrm{t}}$ & $0.078^{* * *}$ & $0.036^{* *}$ & 1 & & & & & & \\
\hline$E A_{\mathrm{i}, \mathrm{t}}$ & $0.067^{* * *}$ & -0.018 & $0.062^{* * *}$ & 1 & & & & & \\
\hline$T A_{i, \mathrm{t}}$ & $0.079^{* * *}$ & $0.115^{* * *}$ & $0.154^{* * *}$ & -0.003 & 1 & & & & \\
\hline$A L R_{\mathrm{i}, \mathrm{t}}$ & $-0.164^{* * *}$ & $-0.081^{* * *}$ & -0.024 & $-0.032 *$ & $0.426^{* * *}$ & 1 & & & \\
\hline$R O A_{\mathrm{i}, \mathrm{t}}$ & $0.418^{* * *}$ & $0.219^{* * *}$ & $0.046^{* *}$ & $-0.047^{* *}$ & $0.089^{* * *}$ & $-0.287^{* * *}$ & 1 & & \\
\hline$O C_{i, t}$ & $0.102^{* * *}$ & $0.058^{* * *}$ & 0.021 & $0.029 *$ & $0.284^{* * *}$ & 0.024 & $0.119^{* * *}$ & 1 & \\
\hline$P I D_{\mathrm{i}, \mathrm{t}}$ & -0.023 & $-0.031^{*}$ & 0.018 & -0.011 & 0.139 *** & $0.037^{* *}$ & -0.006 & $0.083^{* * *}$ & 1 \\
\hline
\end{tabular}

Note: ${ }^{* * *},{ }^{* *}$, and ${ }^{*}$ indicate that they have passed the significance test at the $1 \%, 5 \%$, and $10 \%$ confidence levels, respectively.

\subsection{Baseline Regression Test Results and Analysis}

Table 5 reports the results of the baseline regression test. Before including control variables, the coefficient value of variable $S R F S_{i, t}$ in regression result (1) is positive and significant, showing that better social responsibility performance of foreign shareholders produces stronger international competitiveness of Chinese SOEs. Foreign shareholders' social responsibility engagement would create more international market resources, bringing Chinese SOEs international market recognition to further expand international market resources and occupy more market shares, and consequently increase international competitiveness, in line with H1. In regression result (2), the coefficient of the variable $R \& D_{\mathrm{i}, t}$ is also positive and significant, revealing that higher investment in R\&D innovation will make Chinese SOEs more internationally competitive. It is noted that well-developed R\&D innovation also works to stimulate Chinese SOEs to improve their international competitiveness. Increasing investment in $\mathrm{R} \& \mathrm{D}$ innovation is expected to help Chinese SOEs secure more 
growth potential and space, expand market share, stand out in the international market with new technologies, products, and packaging as a way of enhancing international competitiveness. Further, in regression result (3), which includes the moderating effect of the variable $R \& D_{i, t}$, the coefficient value of the variable $S R F S_{i, t}$ is still positive and significant, and so is the coefficient value of the interaction term $S R F S_{i, t} \times R \& D_{i, t}$, reflecting a greater impact of foreign shareholders' social responsibility on the international competitiveness of Chinese SOEs when R\&D innovation is included. Foreign shareholders themselves would attach great importance to R\&D innovation and consider it as an essential part of fulfilling their social responsibility aiming to elevate enterprises' performance, satisfying the interests of different stakeholders, and exploring more opportunities in international market competition. Therefore, $\mathrm{H} 2$ is verified.

Table 5. Baseline Regression Test Results.

\begin{tabular}{|c|c|c|c|c|c|c|}
\hline & (1) & (2) & (3) & (4) & (5) & (6) \\
\hline$S R F S_{i, t}$ & $\begin{array}{c}0.089^{* * *} \\
(0.010)\end{array}$ & & $\begin{array}{c}0.078^{* * *} \\
(0.014)\end{array}$ & $\begin{array}{c}0.382 * * * \\
(0.089)\end{array}$ & & $\begin{array}{c}0.330 * * * \\
(0.022)\end{array}$ \\
\hline $\begin{array}{c}S R F S_{\mathrm{i}, \mathrm{t}} \times \\
R \mathcal{E} D_{\mathrm{i}, \mathrm{t}}\end{array}$ & & & $\begin{array}{c}0.006^{* * *} \\
(0.001)\end{array}$ & & & $\begin{array}{c}0.042 * * * \\
(0.012)\end{array}$ \\
\hline$R \mathcal{E} D_{\mathrm{i}, \mathrm{t}}$ & & $\begin{array}{c}0.081^{* * *} \\
(0.019)\end{array}$ & $\begin{array}{c}0.073^{* * *} \\
(0.019)\end{array}$ & & $\begin{array}{c}0.454^{* * *} \\
(0.174)\end{array}$ & $\begin{array}{l}0.438^{* *} \\
(0.180)\end{array}$ \\
\hline$E A_{\mathrm{i}, \mathrm{t}}$ & & & & $0.012^{* * *}$ & $0.011^{* * *}$ & $0.012^{* * *}$ \\
\hline$T A_{\mathrm{i}, \mathrm{t}}$ & & & & $0.003 * * *$ & $0.003^{* * *}$ & $0.003^{* * *}$ \\
\hline$A L R_{\mathrm{i}, \mathrm{t}}$ & & & & $-0.025^{* * *}$ & $-0.025^{* * *}$ & $-0.023^{* * *}$ \\
\hline$R O A_{\mathrm{i}, \mathrm{t}}$ & & & & $0.422^{* * *}$ & $0.436^{* * *}$ & $0.422^{* * *}$ \\
\hline$O C_{i, t}$ & & & & $0.020^{* *}$ & $0.021^{* *}$ & $0.021^{* *}$ \\
\hline$P I D_{\mathrm{i}, \mathrm{t}}$ & & & & $-0.021 *$ & $-0.024^{*}$ & $-0.021 *$ \\
\hline Year & Yes & Yes & Yes & Yes & Yes & Yes \\
\hline Industry & Yes & Yes & Yes & Yes & Yes & Yes \\
\hline Constant & $0.187^{* * *}$ & $0.177^{* * *}$ & $0.175^{* * *}$ & $0.112^{* * *}$ & $0.105^{* * *}$ & $0.114^{* * *}$ \\
\hline $\operatorname{Adj} R^{2}$ & 0.028 & 0.006 & 0.033 & 0.194 & 0.191 & 0.196 \\
\hline F-statistics & $89.083^{* * *}$ & $18.424^{* * *}$ & $35.277^{* * *}$ & $105.370^{* * *}$ & $103.302 * * *$ & $82.831^{* * *}$ \\
\hline
\end{tabular}

Note: $* * * * *$, and ${ }^{*}$ indicate they have passed the significance test at the $1 \%, 5 \%$, and $10 \%$ confidence levels, respectively.

When the control variables are added, similar test results appear in regression results (3)-(5), i.e., the coefficient value of variable $S R F S_{i, t}$ is positive and significant, and so is the coefficient value of the interaction term $S R F S_{i, t} \times R \mathcal{E} D_{\mathrm{i}, \mathrm{t}}$. This proves that the social responsibility behavior of foreign shareholders is able to promote the international competitiveness of Chinese SOEs, and R\&D innovation could exert a moderating effect between them. Consequently, this further confirms $\mathrm{H} 1$ and $\mathrm{H} 2$. The traditional corporate competitiveness measured by indicators such as ROA and revenue is relatively manifest, easily quantifiable, and widely accepted in the modern accounting system [35]. However, these indicators may cause inconclusive results in the literature due to sampling problems, reliability, and validity of measures [36,37]. Competitiveness captures not only the manifest indicators but also the latent factors such as potential and process [38]; a wide range of indicators has been included in this study to form a composite index to indicate corporate competitiveness, which can, to some extent, relieve the issue about previous measures. We document a positive association between SRFS and competitiveness. This study argues that CSR engagement will attract valuable resources such as reputation and talents for companies, which help them gain competitiveness in a market.

We conducted several sensitivity tests in order to examine the robustness of our empirical results. Firstly, in view of large differences in economic and market development among different provinces and cities in China, administrative differences may cause resource inequality for SOEs in their regions reflected in foreign capital introduction and international competition. Therefore, we conducted a robustness test after excluding SOEs with operations in Beijing, Shanghai, Tianjin, and Chongqing. Secondly, given the possible 
influence of extreme values, we Winsorized extreme values $(0-1 \%$ and $99-100 \%$ of the sample) and obtained results consistent with those reported previously. Thirdly, the CSR indicators given by Hexun.com include both the total score of social responsibility and the sub-scores of shareholder responsibility, employee responsibility, supplier-customer and consumer-rights responsibility, environmental responsibility, and social responsibility. We considered the five sub-indicators as the dependent variable. The results do not differ substantially from the results previously reported.

\subsection{Endogeneity Regression Test Results and Analysis}

Table 6 reports the results of the endogeneity test. In the regression results of the 1st Stage, the coefficient value of the variable $T P A_{i, t}$ is positive and significant, indicating that foreign shareholders deliver better social responsibility performance among Chinese SOEs involved in targeted poverty alleviation compared with those do not, which validates the relevance of the instrumental variables. In the 2 nd Stage regression results, the coefficient of the variable $S R F S_{i, t}$ is still positive and significant, and so is the coefficient of the interaction term when included. Even after taking endogeneity into account, our results show that a better social responsibility performance by foreign shareholders is associated with stronger international competitiveness of Chinese SOEs. Moreover, R\&D innovation also moderates the relationship between social responsibility of foreign shareholders and international competitiveness of Chinese SOEs, strengthening the effect. Besides, in the regression results (2)-(5) in Table 6, the Sargan test values exhibited by the J statistic validate the instrumental variables chosen for the endogeneity test.

Table 6. Endogeneity Regression Test Results.

\begin{tabular}{|c|c|c|c|c|c|}
\hline & \multirow{2}{*}{$\begin{array}{c}\text { 1st Stage } \\
S R F S_{\mathrm{i}, \mathrm{t}}\end{array}$} & \multicolumn{4}{|c|}{ 2nd-Stage Dependent Variable } \\
\hline & & $I C_{\mathrm{i}, \mathrm{t}}$ & $I C_{\mathrm{i}, \mathrm{t}}$ & $I C_{\mathrm{i}, \mathrm{t}}$ & $I C_{\mathrm{i}, \mathrm{t}}$ \\
\hline & (1) & (2) & (3) & (4) & (5) \\
\hline$T P A_{\mathrm{i}, \mathrm{t}}$ & $\begin{array}{c}0.206^{* * *} \\
(0.088)\end{array}$ & & & & \\
\hline$S R F S_{\mathrm{i}, \mathrm{t}}$ & & $\begin{array}{c}0.057^{* * *} \\
(0.011)\end{array}$ & $\begin{array}{c}0.010 * * * \\
(0.001)\end{array}$ & $\begin{array}{c}0.083^{* * *} \\
(0.022)\end{array}$ & $0.044^{* * *}(0.003)$ \\
\hline$S R F S_{\mathrm{i}, \mathrm{t}} \times R \mathcal{E} D_{\mathrm{i}, \mathrm{t}}$ & & & & $\begin{array}{c}0.099 * * * \\
(0.019)\end{array}$ & $\begin{array}{c}0.079 * * * \\
(0.017)\end{array}$ \\
\hline$R \mathcal{E} D_{\mathrm{i}, \mathrm{t}}$ & & & & $\begin{array}{c}0.035 * * * \\
(0.004)\end{array}$ & $\begin{array}{c}0.020 * * * \\
(0.003)\end{array}$ \\
\hline Control_Variable & Yes & No & Yes & No & Yes \\
\hline Year & Yes & Yes & Yes & Yes & Yes \\
\hline Industry & Yes & Yes & Yes & Yes & Yes \\
\hline Constant & $0.392 * * *$ & $0.186^{* * *}$ & $0.130^{* * *}$ & $0.180^{* * *}$ & $0.130^{* * *}$ \\
\hline $\operatorname{Adj} R^{2}$ & 0.014 & 0.056 & 0.189 & 0.056 & 0.188 \\
\hline F-statistics & $19.989^{* * *}$ & $80.006^{* * *}$ & $45.386^{* * *}$ & $27.237^{* * *}$ & $35.358^{* * *}$ \\
\hline J-statistics & - & 0.444 & 0.708 & 0.582 & 0.726 \\
\hline
\end{tabular}

Note: $(1)^{* * *}$ indicates that they have passed the significance test at the $1 \%$ confidence levels. (2) The sample interval for the endogeneity test in Table 6 is 2016-2019 with a sample size of 1335, as Chinese enterprises started to publicly disclose information on targeted poverty alleviation in 2016.

\subsection{Heterogeneity Grouping Regression Test Results and Analysis}

\subsubsection{Grouping Test between Central SOEs and Local SOEs}

Chinese SOEs are divided into central SOEs and local SOEs, which differ in business objectives, business practices, corporate governance, and property rights objectives [39]. In the sample of the study, central SOEs accounted for $28.61 \%$ of the total, while local SOEs accounted for $71.39 \%$. We therefore tested whether differences exist in the impact of social responsibility of foreign shareholders on the international competitiveness of central SOEs and local SOEs. 
Table 7 presents the grouping test results for central SOE and local SOE samples. The coefficient value of the variable SRFSi,t remains positive and significant in both central and local SOE samples, and the coefficient value of the interaction term SRFSi,t $\times R \mathcal{E D} \mathrm{i}$, $\mathrm{t}$ is also positive and significant, implying that social responsibility of foreign shareholders can boost the international competitiveness of both central and local SOEs. The moderating effect of R\&D innovation is also observed. Both Chinese central and local SOEs share a unified development mindset and philosophy, and therefore foreign shareholders' social responsibility performance would fully leverage international competitiveness. Furthermore, a comparison of the results of different sample tests reveals that the coefficient values are greater for the Chinese local SOE sample. This implies that social responsibility of foreign shareholders exercises a greater impact on international competitiveness among Chinese local SOEs.

Table 7. Grouping Test Results for Central SOEs and Local SOEs.

\begin{tabular}{|c|c|c|c|c|c|c|c|c|}
\hline & \multicolumn{4}{|c|}{ Sample of Central SOEs } & \multicolumn{4}{|c|}{ Sample of Local SOEs } \\
\hline & (1) & (2) & (3) & (4) & (5) & (6) & (7) & (8) \\
\hline & $0.023^{* * *}$ & $0.005^{* * *}$ & $0.015^{* * *}$ & $0.008^{* *}$ & $0.041^{* * *}$ & $0.010^{* * *}$ & $0.022 * * *$ & $0.010 * * *$ \\
\hline$S R F S_{i, t}$ & $(0.002)$ & $(0.002)$ & $(0.003)$ & $(0.003)$ & $(0.001)$ & $(0.001)$ & $(0.003)$ & $(0.002)$ \\
\hline SRFS. $\times R \mathcal{E} D$. & & & $0.020^{* * *}$ & $0.022^{* * *}$ & & & $0.013^{* * *}$ & $0.011^{* * *}$ \\
\hline$S R F S_{i, t} \times R \delta D_{i, t}$ & & & $(0.002)$ & $(0.002)$ & & & $(0.001)$ & $(0.002)$ \\
\hline & & & $0.013^{* * *}$ & $0.028^{* * *}$ & & & $0.049 * *$ & $0.043^{* *}$ \\
\hline$R \mathcal{E} D_{\mathrm{i}, \mathrm{t}}$ & & & $(0.003)$ & $(0.008)$ & & & $(0.023)$ & $(0.020)$ \\
\hline Control_Variable & No & Yes & No & Yes & No & Yes & No & Yes \\
\hline Year & Yes & Yes & Yes & Yes & Yes & Yes & Yes & Yes \\
\hline Industry & Yes & Yes & Yes & Yes & Yes & Yes & Yes & Yes \\
\hline Constant & $0.195^{* * *}$ & $0.145^{* * *}$ & $0.174^{* * *}$ & $0.139 * * *$ & $0.183^{* * *}$ & $0.102^{* * *}$ & $0.175^{* * *}$ & $0.106^{* * *}$ \\
\hline$N$ & 867 & 867 & 867 & 867 & 2163 & 2163 & 2163 & 2163 \\
\hline $\operatorname{Adj} R^{2}$ & 0.011 & 0.126 & 0.026 & 0.132 & 0.035 & 0.211 & 0.037 & 0.212 \\
\hline F-statistics & $10.627^{* * *}$ & $21.787^{* * *}$ & $8.700 * * *$ & $17.430^{* * *}$ & $79.137^{* * *}$ & $97.381^{* * *}$ & $28.504^{* * *}$ & $73.534^{* * *}$ \\
\hline
\end{tabular}

Note: ${ }^{* * *}$ and ${ }^{* *}$ indicate they have passed the significance test at $1 \%$ and $5 \%$ confidence levels.

\subsubsection{Grouping Test of Commercial SOEs and Public Welfare SOEs}

On December 27, 2015, China's State-owned Assets Supervision and Administration Commission (SASAC), Ministry of Finance, and National Development and Reform Commission issued the Guidance on the Functional Definition and Classification of Stateowned Enterprises. SOEs are divided into commercial SOEs and public welfare SOEs, and different categories of SOEs require corresponding market mechanisms and market environments [40], coupled with various performance evaluation indicators. Therefore, different types of SOEs face separate requirements while expanding overseas markets and enhancing competitiveness in international markets. In this sample, commercial SOEs account for $66.63 \%$ of the total, while public welfare SOEs account for $33.37 \%$. We conducted a group test to examine whether there is a difference in the impact of the social responsibility of foreign shareholders on international competitiveness among commercial SOEs and public welfare SOEs.

Table 8 presents the grouping tests results for the samples of commercial SOEs and public welfare SOEs. The coefficient value of the variable $S R F S_{\mathrm{i}, \mathrm{t}}$ remains positive and significant in both commercial and public welfare SOE, and the coefficient value of the interaction term $S R F S_{\mathrm{i}, \mathrm{t}} \times R \mathcal{E} D_{\mathrm{i}, \mathrm{t}}$ is also positive and significant, indicating that foreign shareholders' social responsibility boosts the international competitiveness of commercial and local Chinese SOEs, and that R\&D innovation strengthens this effect. Both commercial and public welfare SOEs are well positioned to fully play the role of foreign shareholders social responsibility engagement during international competition so as to better seize competitive opportunities supported by R\&D innovation. We also find that the coefficient values of Chinese commercial SOEs are greater after further comparing the results of different sample tests. This implies that the social responsibility of foreign shareholders could 
have a stronger impetus on the international competitiveness of Chinese commercial SOEs, which is also related to the fact that commercial SOEs face fiercer market competition and more intense market resource grabbing, making it more imperative for foreign shareholders to strengthen their international competitiveness by fulfilling social responsibility.

Table 8. Grouping Test Results for Commercial SOEs and Public Welfare SOEs.

\begin{tabular}{|c|c|c|c|c|c|c|c|c|}
\hline & \multicolumn{4}{|c|}{ Sample of Commercial SOEs } & \multicolumn{4}{|c|}{ Sample of Public Welfare SOES } \\
\hline & (1) & (2) & (3) & (4) & (5) & (6) & (7) & (8) \\
\hline$S R F S_{\mathrm{i}, \mathrm{t}}$ & $\begin{array}{c}0.040^{* * *} \\
(0.001)\end{array}$ & $\begin{array}{c}0.011^{* * *} \\
(0.001)\end{array}$ & $\begin{array}{c}0.080 * * * \\
(0.003)\end{array}$ & $\begin{array}{c}0.015^{* * *} \\
(0.004)\end{array}$ & $\begin{array}{c}0.032 * * * \\
(0.001)\end{array}$ & $\begin{array}{c}0.006^{* * *} \\
(0.001)\end{array}$ & $\begin{array}{c}0.031^{* * *} \\
(0.002)\end{array}$ & $\begin{array}{c}0.006^{* * *} \\
(0.001)\end{array}$ \\
\hline$S R F S_{\mathrm{i}, \mathrm{t}} \times R \mathcal{E} D_{\mathrm{i}, \mathrm{t}}$ & & & $\begin{array}{c}0.026^{* * *} \\
(0.002)\end{array}$ & $\begin{array}{c}0.025^{* * *} \\
(0.002)\end{array}$ & & & $\begin{array}{c}0.043^{* * *} \\
(0.002)\end{array}$ & $\begin{array}{c}0.041 \text { *** } \\
(0.001)\end{array}$ \\
\hline$R \mathcal{E} D_{\mathrm{i}, \mathrm{t}}$ & & & $\begin{array}{c}0.093^{* * *} \\
(0.002)\end{array}$ & $\begin{array}{c}0.056^{* * *} \\
(0.002)\end{array}$ & & & $\begin{array}{c}0.036^{* * *} \\
(0.003)\end{array}$ & $\begin{array}{c}0.029 * * * \\
(0.003)\end{array}$ \\
\hline Control_Variable & No & Yes & No & Yes & No & Yes & No & Yes \\
\hline Year & Yes & Yes & Yes & Yes & Yes & Yes & Yes & Yes \\
\hline Industry & Yes & Yes & Yes & Yes & Yes & Yes & Yes & Yes \\
\hline Constant & $0.191^{* * *}$ & $0.022 * * *$ & $0.176^{* * *}$ & $0.025^{* * *}$ & $0.178^{* * *}$ & $0.245^{* * *}$ & $0.172 * * *$ & $0.252 * * *$ \\
\hline$N$ & 2019 & 2019 & 2019 & 2019 & 1011 & 1011 & 1011 & 1011 \\
\hline $\operatorname{Adj} R^{2}$ & 0.031 & 0.224 & 0.037 & 0.225 & 0.028 & 0.186 & 0.037 & 0.193 \\
\hline F-statistics & $65.790^{* * *}$ & $83.992^{* * *}$ & $26.808^{* * *}$ & $66.237^{* * * *}$ & $30.334^{* * *}$ & $34.017^{* * *}$ & $14.014^{* * *}$ & $27.922^{* * *}$ \\
\hline
\end{tabular}

Note: ${ }^{* * *}$ indicates they have passed the significance test at the $1 \%$ confidence level.

\subsubsection{Grouping Test of Manufacturing SOEs and Non-Manufacturing SOEs}

Industries differ in their social responsibility performance, with enterprises from the manufacturing industry receiving extra attention. The reason behind this is that manufacturing enterprises are often faced with problems such as environmental pollution in production and operation. Nevertheless, in recent years, Chinese manufacturing companies, especially major ones, have been devoted to conceiving and practicing social responsibility [41]. In our sample, manufacturing SOEs account for $70.30 \%$ of the total, while non-manufacturing SOEs account for $29.70 \%$. Next, we test whether the influence of the social responsibility of foreign shareholders on international competitiveness differs between manufacturing SOEs and non-manufacturing SOEs.

Table 9 reports the grouping test results for manufacturing SOE and non-manufacturing SOE samples. The coefficient value of the variable $S R F S_{i, t}$ remains positive and significant for both manufacturing SOE and non-manufacturing SOE samples, while the coefficient value of the interaction term $S R F S_{i, t} \times R \& D_{\mathrm{i}}$, is also positive and significant, showing that social responsibility of foreign shareholders increases the international competitiveness of Chinese SOEs and that R\&D innovation strengthens this effect. Both manufacturing SOEs and non-manufacturing SOEs fully deliver the role of foreign shareholders' social responsibility performance, while pressures and motivation thus generated make Chinese SOEs more internationally competitive. Further, a comparison of different sample test results reveals that the coefficient values of the test results are greater in the Chinese manufacturing SOE sample, which indicates that social responsibility of foreign shareholders could better propel the international competitiveness of Chinese manufacturing SOEs. This may be due to stronger social responsibility expectations and actions of manufacturing enterprises. For instance, some manufacturing enterprises are expected to achieve full coverage of green management, R\&D innovation, production, and marketing processes from the organizational level through green consciousness and technology innovation involved in social responsibility, and finally shape a green brand image and win consumers' trust as a way of capturing a greater international market [42]. For another thing, in recent years, an increasing number of Chinese manufacturing SOEs have made full use of foreign shareholders imported through mixed-ownership reform. More Chinese manufacturing 
SOEs have entered into international competition and made themselves known in the international market.

Table 9. Grouping Test Results for Manufacturing SOEs and Non-manufacturing SOEs.

\begin{tabular}{|c|c|c|c|c|c|c|c|c|}
\hline & \multicolumn{4}{|c|}{ Sample of Manufacturing SOEs } & \multicolumn{4}{|c|}{ Sample of Non-Manufacturing SOEs } \\
\hline & (1) & (2) & (3) & (4) & (5) & (6) & (7) & (8) \\
\hline$S R F S_{\mathrm{i}, \mathrm{t}}$ & $\begin{array}{c}0.049^{* * *} \\
(0.012)\end{array}$ & $\begin{array}{c}0.012^{* * *} \\
(0.001)\end{array}$ & $\begin{array}{c}0.064^{* * *} \\
(0.005)\end{array}$ & $\begin{array}{c}0.017^{* * * *} \\
(0.006)\end{array}$ & $\begin{array}{c}0.042^{* * *} \\
(0.012)\end{array}$ & $\begin{array}{c}0.008^{* * *} \\
(0.001)\end{array}$ & $\begin{array}{c}0.046^{* * *} \\
(0.002)\end{array}$ & $\begin{array}{l}0.004 \text { * } \\
(0.002)\end{array}$ \\
\hline$S R F S_{\mathrm{i}, \mathrm{t}} \times R \mathcal{E} D_{\mathrm{i}, \mathrm{t}}$ & & & $\begin{array}{c}0.083^{* * *} \\
(0.028)\end{array}$ & $\begin{array}{c}0.030^{* * * *} \\
(0.003)\end{array}$ & & & $\begin{array}{c}0.019 * * * \\
(0.005)\end{array}$ & $\begin{array}{c}0.016^{* * *} \\
(0.001)\end{array}$ \\
\hline$R \mathcal{E} D_{\mathrm{i}, \mathrm{t}}$ & & & $\begin{array}{c}0.050^{* * *} \\
(0.003)\end{array}$ & $\begin{array}{c}0.015^{* * *} \\
(0.003)\end{array}$ & & & $\begin{array}{c}0.032 * * * \\
(0.002)\end{array}$ & $\begin{array}{c}0.025^{* * *} \\
(0.002)\end{array}$ \\
\hline Control_Variable & No & Yes & No & Yes & No & Yes & No & Yes \\
\hline Year & Yes & Yes & Yes & Yes & Yes & Yes & Yes & Yes \\
\hline Industry & Yes & Yes & Yes & Yes & Yes & Yes & Yes & Yes \\
\hline Constant & $0.187^{* * *}$ & $0.091^{* * *}$ & $0.161^{* * *}$ & $0.092^{* * *}$ & $0.185^{* * *}$ & $0.131^{* * *}$ & $0.181^{* * *}$ & $0.135 * * *$ \\
\hline N & 2130 & 2130 & 2130 & 2130 & 900 & 900 & 900 & 900 \\
\hline $\operatorname{Adj} R^{2}$ & 0.038 & 0.213 & 0.046 & 0.213 & 0.012 & 0.151 & 0.013 & 0.151 \\
\hline F-statistics & $85.850^{* * *}$ & $83.399^{* * *}$ & $34.912 * * *$ & $65.143^{* * * *}$ & $11.942^{* * *}$ & $23.847^{* * *}$ & $4.982 * * *$ & $18.787^{* * *}$ \\
\hline
\end{tabular}

Note: ${ }^{* * *},{ }^{*}$ indicate they have passed the significance test at the $1 \%$ and $10 \%$ confidence levels, respectively.

\section{Conclusions}

Over the past few years, a rising number of Chinese SOEs have introduced foreign shareholders through mixed-ownership reform as a way of standing out in international market competition with capital, technology, information, and management brought along with it. Foreign shareholders' emphasis on social responsibility aims to make Chinese SOEs internationally competitive. Therefore, in this paper we empirically examine the impact of foreign shareholders' social responsibility on the international competitiveness of Chinese SOEs and the moderating effect of R\&D innovation. Specifically, we draw on a sample of Chinese listed SOEs with international market operations during 20112019. We find that foreign shareholders' social responsibility can effectively enhance the international competitiveness of Chinese SOEs, i.e., the better foreign shareholders perform social responsibility, the stronger the international competitiveness of Chinese SOEs will be. Moreover, we find that R\&D innovation has a strengthening and a moderating effect between foreign shareholders' social responsibility and enterprises' international competitiveness, that is, greater R\&D innovation of Chinese SOEs makes the contribution of foreign shareholders' social responsibility to international competitiveness stronger. These findings are also valid after controlling for several robustness tests and endogeneity issues. Additional tests show that the contribution of foreign shareholders' social responsibility to the international competitiveness of Chinese SOEs is more pronounced among Chinese local SOEs, commercial SOEs, and manufacturing SOEs, and the same is true for the moderating effect.

Our study, therefore, makes several contributions to the literature. By focusing on foreign shareholders and by analyzing the benefits that foreign shareholders can bring to Chinese SOEs, we contribute toward extending the relatively scarce literature on the mixed-ownership reform of Chinese SOEs. Specifically, we believe our findings are useful as they offer empirical evidence on how foreign shareholders and their social responsibility performance promote Chinese SOEs. In that sense, they deepen our understanding of the reasons why Chinese SOEs introduce foreign shareholders and their roles in the mixedownership reform. Our study underlines social responsibility as one important mechanism through which foreign shareholders play a significant role in and affect the international competitiveness of Chinese SOEs.

Our study also makes important contributions for practitioners and policy-makers. Building on our results, our study suggests several measures that can be taken in order to enhance the international competitiveness of Chinese SOEs: first, the role of foreign 
shareholders is underlined. In the mixed-ownership reform of Chinese SOEs, private shareholders are still preferred, with foreign shareholders ranked after. Nevertheless, foreign shareholders are less associated with state-owned shareholders, leading to governance advantages in particular. In that way, Chinese SOEs could achieve better results if they embrace mixed-ownership reform. Secondly, the advantages provided by foreign shareholders should be fully exploited. Some Chinese SOEs have introduced foreign shareholders but failed to utilize them effectively. Given this, it could be convenient to grant foreign shareholders more autonomy in the enterprise, such as participating in management and increasing voting rights, so that foreign shareholders can provide not only capital, but also technology and management, all of which is conducive to the sound growth of SOEs. Overall, the empirical evidence provided in this paper about the improvement of the international competitiveness of Chinese SOEs when foreign shareholders are included can be of great reference value to Chinese SOEs implementing mixed-ownership reforms and to policy-makers of related policies.

\section{Limitations and Avenues for Future Research}

Our study is naturally subject to limitations. First, specific firm-level characteristics could play an important role in and affect the relationships analyzed in this paper. For example, the age of the firm can be an important factor affecting the development of its operations, which deserves further attention in future studies. Second, although we included industry dummies in our models, we must acknowledge that specific industry characteristics may affect the international competitiveness of Chinese SOEs. We therefore encourage scholars to conduct further analyses of specific industries as well as in-depth comparative analyses of different industries to enlarge our knowledge of the specificities of each sector.

Author Contributions: Conceptualization, Y.Z., C.L. and A.J.; methodology, Y.Z., C.L. and A.J.; formal analysis, Y.Z., C.L. and A.J.; investigation, Y.Z., C.L. and A.J.; writing-original draft preparation, Y.Z. and C.L.; writing — review and editing, A.J.; funding acquisition, Y.Z. and C.L. All authors have read and agreed to the published version of the manuscript.

Funding: This research was funded by the Chongqing Social Science Planning Youth Project, grant number 2018QNGL37, and Youth Fund of Humanities and Social Sciences, Ministry of Education of China, grant number 18YJC630087.

Institutional Review Board Statement: Not applicable.

Informed Consent Statement: Not applicable.

Data Availability Statement: The data presented in this study are available on request from the corresponding author. The data are not publicly available due to privacy.

Conflicts of Interest: The authors declare no conflict of interest.

\section{References}

1. Jiang, X.J. On the Transformation of Models of Use of Foreign Capital versus the Transformation of Economic Growth Models. Manag. World 1999, 15, 7-15.

2. Li, Z.C.; Ma, X.M.; Chen, Y. Practice, Effect, Experience and Countermeasures of China's Utilization of Foreign Capital Since the Reform and Open Up. Intertrade 2019, 38, 58-67.

3. Wu, C.Q.; Lv, Z.Y. Privatization, Foreign Shareholder and Embeddedness: Evidence from China. Bus. Manag. J. 2011, 33, 51-58.

4. Deng, Z.L.; Chen, Y. The Influence of Foreign Direct Investment on the Survival of State-owned Enterprises: A Study based on the Heterogeneity of Enterprises. J. World Econ. 2013, 36, 53-69.

5. Ma, L.F.; Wang, L.L.; Zhang, Q. Pecking Order of Mixed Ownership: The Logic of Market. China Ind. Econ. 2015, 33, 5-20.

6. Letchumanan, R.; Kodama, F. Reconciling the Conflict Between the 'Pollution-Haven' Hypothesis and an Emerging Trajectory of International Technology Transfer. Res. Policy 2000, 29, 59-79. [CrossRef]

7. Shao, M.; Bao, Q. The Influence of FDI on China's Domestic Labor Rights and Interests. Manag. World 2013, 29, 32-43.

8. Wang, H.M.; Lv, X.J.; Lin, W.F. The Effect of Foreign Equity Participation,Executive Ownership,Institutional Ownership on Corporate Social Responsibility. Account. Res. 2014, 35, 81-87. 
9. Huang, W.; Chen, Z. Foreign Capital Entry, Supply Chain Pressure and Chinese Corporate Social Responsibility. Manag. World 2015, 31, 91-100.

10. Bu, D.L.; He, C.; Wen, C.H. How does Foreign Shareholder Affect Corporate Social Responsibility. Account. Res. $2021,42,86-101$.

11. Aggarwal, R.; Ere, I.; Ferreira, M.; Matos, P. Does Governance Travel around the World: Evidence from Institutional Investors. J. Financ. Econ. 2011, 100, 154-181. [CrossRef]

12. Gangi, F.; Mustilli, M.; Varrone, N. The Impact of Corporate Social Responsibility (CSR) Knowledge on Corporate Financial Performance: Evidence from the European Banking Industry. J. Knowl. Manag. 2019, 23, 110-134. [CrossRef]

13. Child, J. A Foreign Perspective on the Management of People in China. Int. J. Hum. Resour. Manag. 1991, 2, 93-107. [CrossRef]

14. Chapple, W.; Moon, J. Corporate Social Responsibility (CSR) in Asia: A Seven-Country Study of CSR Web Site Reporting. Bus. Soc. 2005, 44, 415-441. [CrossRef]

15. Barako, D.G.; Hancock, P.; Izan, H.Y. Factors Influencing Voluntary Corporate Disclosure by Kenyan Companies. Corp. Gov. Int Rev. 2006, 14, 107-125. [CrossRef]

16. In, F.; Kim, M.; Park, R.J. Competition of Socially Responsible and Conventional Mutual Funds and Its Impact on Fund Performance. J. Bank. Financ. 2014, 44, 160-176. [CrossRef]

17. Ma, L.L. Research on the Influence Mechanism of Corporate Social Responsibility on Consumers' Purchase Intention. Manag. World 2011, 27, 120-126.

18. Lall, S. Vertical Inter-Firm Linkages in LDCs: An Empirical Study. Oxf. Bull. Econ. Stat. 1980, 42, 203-226. [CrossRef]

19. Zheng, S.F.; Huang, L.Y. Impact of Foreign Direct Investment Entry on Corporate Social Responsibility: Based on Intra-industry and Inter-industry Spillover Effects. J. Int. Trade 2018, 44, 116-129.

20. Ruf, B.M.; Muralidhar, K.; Brown, R.M.; Janney, J.J.; Paul, K. An Empirical Investigate of the Relationship between Change in Corporate Social Performance and Financial Performance: A Stakeholder Theory Perspective. J. Bus. Ethics 2001, 32, 143-156. [CrossRef]

21. Petersen, H.L.; Vredenburg, H. Morals or Economics: Institutional Investor Preferences for Corporate Social Responsibility. J. Bus. Ethics 2009, 90, 1-14. [CrossRef]

22. Lin, B.; Rao, J. Why do Listed Companies Disclose the Auditor's Internal Control Reports Voluntarily: An Empirical Study Based on Signaling Theory in China. Account. Res. 2009, 30, 45-52.

23. Friedman, M. The Social Responsibility of Business is to Increase its Profit. N. Y. Times Mag. 1970, 13, $122-126$.

24. Du, W.J.; Li, M.J. A Research on Enterprise Innovation-Driven Mechanism in the Open Economy. Sci. Res. Manag. 2018, 39, 91-98.

25. Küçükoglu, M.T.; Pınar, R.İ. Positive Influences of Green Innovation on Company Performance. Procedia-Soc. Behav. Sci. 2015, 195, 1232-1237. [CrossRef]

26. Zheng, S.L.; Zhang, M.C. Estimating the Contribution of China's Scientific and Technological Progress to Economic Growth: 1990-2017. J. World Econ. 2019, 42, 73-97.

27. Li, X.H.; Wang, Y.F. Data Value Chain and the Mechanism of Value Creation. Econ. Rev. J. 2020, 36, 54-62.

28. Cheng, K.Y.; Lin, P. Spillover Effects of FDI on Innovation in China: Evidence from Provincial Data. China Econ. Rev. 2004, 15, 25-44. [CrossRef]

29. Ortas, E.; Gallego-Alvarez, I.; Etxeberria, I.A. Financial Factors Influencing the Quality of Corporate Social Responsibility and Environmental Management Disclosure: A Quantile Regression Approach. Corp. Soc. Responsib. Environ. Manag. 2015, 22, 362-380. [CrossRef]

30. Brammer, S.; Millington, A. Corporate Reputation and Philanthropy: An Empirical Analysis. J. Bus. Ethics 2005, 61, 29-44. [CrossRef]

31. Carrasco, I.; Buendia, M. Corporate Social Responsibility: A Crossroad between Changing Values, Innovation and Internationalization. Eur. J. Int. Manag. 2013, 7, 295-314.

32. Luong, H.; Moshirian, F.; Nguyen, L.; Tian, X.; Zhang, B. How do Foreign Institutional Investors Enhance Firm Innovation. J. Financ. Quant. Anal. 2017, 52, 1449-1490. [CrossRef]

33. Iyer, D.N.; Miller, K.D. Performance Feedback, Slack, and the Timing of Acquisitions. Acad. Manag. J. 2008, 51, 808-822.

34. Chen, H.; Xu, R. Research on the International Competitiveness of Chinese and American Listed Companies: An Empirical Analysis Based on High-end Manufacturing and Information Technology Industry. Stud. Int. Financ. 2016, 33, 49-61.

35. Long, W.; Li, S.; Wu, H.; Song, X. Corporate social responsibility and financial performance: The roles of government intervention and market competition. Corp. Soc. Responsib. Environ. Manag. 2020, 27, 525-541. [CrossRef]

36. Margolis, J.D.; Walsh, J.P. Misery loves companies: Rethinking social initiatives by business. Adm. Sci. Q. 2003, 48, 268-305. [CrossRef]

37. Orlitzky, M.; Schmidt, F.L.; Rynes, S.L. Corporate social and financial performance: A meta-analysis. Organ. Stud. 2003, 24, 403-441. [CrossRef]

38. Buckley, P.J.; Pass, C.L.; Prescott, K. Measures of international competitiveness: A critical survey. J. Mark. Manag. 1988, 4, 175-200. [CrossRef]

39. Chen, S.H.; Lu, C.C. Can the Governance Participation of Party Organizations in State-owned Enterprises Effectively Curb the 'Loss of State-owned Assets' in Mergers and Acquisitions. Manag. World 2014, 30, 106-120.

40. Xie, L.Y. The Boundary between Government and Market in the Classification Reform of State-owned Enterprises. Dyn. Soc. Sci. 2017, 40, 35-39. 
41. Feng, D.L. Trends and Problems of China's Manufacturing Large Enterprises Outward Internationalization and Its Countermeasures. Intertrade 2020, 39, 31-37.

42. Sueyoshi, T.; Wang, D. Radial and Non-Radial Approaches for Environmental Assessment by Data Envelopment Analysis: Corporate Sustainability and Effective Investment for Technology Innovation. Energy Econ. 2014, 45, 537-551. [CrossRef] 